\title{
Investment Strategies, Trading Information And Option Market: Evidence From The Toronto Stock Exchange.
}

Tov Assogbavi, Laurentian University, Canada

Siméon Fagnissè, Université de Parakou, Parakou, Rép. du Bénin

\begin{abstract}
This paper empirically investigates the relationship between equity price change and volume in order to determine the extent to which option trading affects the absolute price-volume relationship. The analysis is based on Zellner's 'Seemingly Unrelated Regression, (SUR) method shows that, on average, the trading volume of option eligible equity issues is less sensitive to price changes than the volume of equity issues without options. This result supports the hypothesis (Ross, 1976) that investors may be more inclined to turn to the option market rather than acting directly on the securities in order to carry out their different investment strategies on the stock market. A direct implication of this finding suggests that investment strategies that use both volume and price change to make inferences for investment decisions have to integrate, at least when dealing with an option eligible equity, both stock and option markets into their analysis.
\end{abstract}

\section{INTRODUCTION}

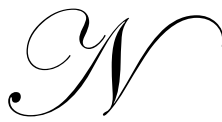

umerous studies based mostly on U.S. data have attempted to describe and explain the relationship between price changes and trading volume. Beginning with Osborne (1959), this relationship has been studied from a variety of perspectives and the findings indicate that there is a positive correlation between absolute price changes and trading volumes, both in stock and futures markets. Recent studies indicated that strategies that take into account trading volume are consistently outperforming strategies that are only based on price (Jennifer, Hameed, and Niden 1994; Assogbavi 1999). Overall, these studies show that additional information on trading activity appears to be an important predictor of the return on an individual equity. The emergence of public exchanges for the trading of stock options along with the seminal article by Black and Scholes (1973) has spawned considerable interest in this topic in recent years. Option pricing under alternative assumptions and its application to other types of securities has been extensively examined in the financial literature. However, little research effort has been devoted to analyzing the impact option trading has on the price-volume relationship. Consistent with Ross (1976), options exist to increase trading opportunities, i.e., to cover all possible contingencies. From this viewpoint, the investor's reaction to new information, conveyed by price changes, can be observed both in option and stock markets. The importance of the price-volume relationship in the structure of financial markets, the debate over empirical distribution of speculative prices (Rogalski 1978) and the event studies by Beaver (1968) point to a need to analyze whether the introduction of the option market has indeed modified the nature of the observed price-volume relationship.

The purpose of this paper is to examine how the option market affects the relationship between price changes and trading volume. Empirically, it is to be expected that the correlation between price change and trading volume on option eligible equities would be less strong than in equities without options.

The remainder of the paper is divided into four sections. Section II presents a brief literature review of absolute price-volume relationship. The data and the methodology for the empirical test are described in section III. The results are analyzed in section IV. The last section summarizes and concludes the paper. 


\section{LITERATURE REVIEW}

Based on Osborne's (1959) early work on the price-volume relationship, many theories have been put forward to explain the positive relationship between trading volume and absolute price changes. The most plausible of such theories are those which rely on the way the information is disseminated to explain the positive correlation between price change and trading volume. The theories based on simultaneous information arrival as developed by Epps (1975), Tauchen and Pitts (1983), Pfleiderer (1984), and Harris (1986) assume that the information is disseminated to all investors at the same time. They show that there is a positive correlation between trading volume and absolute price changes. But the criticism by Schneller (1978) and Karpoff (1987) shows that the Epps model supposes irrational behavior on the part of investors. On the other hand, the theories based on sequential arrival of information developed by Copeland (1976, 1977) and extended by Jennings, Starks, and Fellingham (1981) suppose that the information is disseminated to only one trader at a time. They assume that the trading volume and the price change are sequentially determined. However, they arrive at the same conclusion as that of simultaneous information arrival models, that is, a large increase in volume is usually accompanied by either a large rise in price or a large fall in price consistent with a positive correlation between volume and absolute price change. Indeed, numerous empirical findings support the positive volume-absolute price change correlation for both market indices and individual stocks, confirming the old Wall Street saying: "It takes volume to make prices move". The observations used in those studies vary from yearly to transactional data. An understanding of the relation between stock prices and volume is important for a number of reasons ${ }^{1}$.

According to Ross (1976), options exist to increase trading opportunities, in order to cover all possible contingencies. From this viewpoint, the investor's reaction to a new piece of information, conveyed by price changes, can be observed both in option and stock markets. Indeed, the advantages attached to option trading, in the present instance, the low transaction cost and the possibility of risk transfer, allow the investor holding a security, the price of which he expects to fall, to react by buying a put or selling a call on the security in question, instead of directly selling it. From this it follows that for two comparable securities, one with options and the other without, one would expect that the trading volume of option eligible equities would be differently affected by price changes than would equity issues without options. This means that the relationship between trading volume and price changes of the former would be significantly weaker than that of the latter. More recent studies have shown that information on trading activity appears to be an important predictor of the returns of individual securities. Following Blume, Easley, and O'Hara (1994) and Campbell, Grossman, and Wang (1993), Jennifer, Conrad Hameed and Niden (1994) have developed a variant of Lehmann's (1990) strategy to test for the relations between trading volume and subsequent returns patterns in individual securities'short-horizon returns. Specifically, they found that high-transaction securities experience price reversals, while the returns of low-transactions securities are positively auto-correlated. This finding is later confirmed by Sarwar (2005). If the introduction of the option market does bring about changes in price-volume relationship, it then appears important to analyze its impact on the spot market. In this case, when dealing with an option eligible equity, investment strategies that use both volume and price change to make investment decisions must include both stock and option markets in their analysis.

\section{DATA AND METHODOLOGY}

The data used in this study consist of time-ordered daily prices and daily transaction volumes of 33 of the 35 stocks that make up the TOR35 composite index. The TOR35 index was launched by the Toronto Stock Exchange to circumvent the liquidity problem inherent in the TSE300. It is comprised of 35 out of the 50 blue chip Canadian equities. Of the 33 stocks studied, 20 are optionable and the remaining 13 are not. The data comprise open prices $\left(\mathrm{P}_{\mathrm{o}}\right)$, close prices $\left(\mathrm{P}_{\mathrm{c}}\right)$, highs $(\mathrm{H})$, lows $(\mathrm{L})$, and trading volumes. The period covered ${ }^{2}$ by the study extends from April 01, 1994 to May 27, 1995. To avoid the bias that might be directly related to the missing values

\footnotetext{
${ }^{1}$ According to Karpoff (1987), there are many reasons why the understanding of the relation between stock prices and volume is important. The price-volume relation study can help to: a) discriminate between competing theories on how information is disseminated in financial markets, b) infer the information content in event studies, c) assess the distribution of returns (Epps and Epps, 1976), and d) better understand the technical analysis (Blume et al, 1994).

${ }^{2}$ In order to keep contuniuty in the data, 33 instead of 35 stocks were retained and also the observations are limited to 1995.
} 
problem, all information for which there was no price change is excluded from the sample. After this adjustment, the final sample was reduced to a total ranging from 226 to 302 observations. In this analysis, trading volume (V) is measured by the number of shares. Price changes on the other hand could be measured in a number ways. Measures such as the difference between open and close prices, high and low prices, security returns based on close prices, and absolute value of price changes have all been used in the literature. In this paper, price changes $(\Delta \mathrm{P})$ will be measured as the difference between two consecutive closing prices $\left(\Delta \mathrm{P}_{\mathrm{cc}}\right)$. Indeed, our preliminary evidence shows that tests based on the relative measure of price changes as measured by closing price returns, $\mathrm{RT}_{t}=\left[\left(\mathrm{P}_{\mathrm{c}, \mathrm{t}}-\mathrm{P}_{\mathrm{c}, \mathrm{t}-1}\right)\right.$ / $\left.P_{c, t-1}\right]$, yield the same results as those using the absolute value of price changes $\left(\left|\Delta P_{t}\right|\right)$, in terms of signs of coefficients and relative level of significance. Similar findings were also reported by Chamberlain et al. (1991). However, for comparison purposes, we shall also use the difference between open and close prices $\left(\Delta \mathrm{P}_{\mathrm{oc}}\right)$, as well as that between high and low prices $\left(\Delta \mathrm{P}_{\mathrm{hl}}\right)$ as measures of price change. According to Karpoff $(1987,1988)$, the positive linear relationship between trading volume and the absolute value of the price change can be formulated as follows:

$$
\mathrm{V}_{\mathrm{i}}=\alpha_{\mathrm{i}}+\beta_{\mathrm{I}}\left|\Delta \mathrm{P}_{\mathrm{I}}\right|+\xi_{\mathrm{i}}
$$

where $\mathrm{V}_{\mathrm{i}}, \Delta \mathrm{P}_{\mathrm{i}}$ and $\xi_{\mathrm{I}}$ are trading volume, price change, and the error term, respectively, for security i.

To analyze the price-volume relationship, we estimate regression equation (1) by applying Zellner's Seemingly Unrelated Regression (SUR) with linear equality constraints imposed on the estimates of the coefficient $\beta_{1 \mathrm{i}}$ and the average of these coefficients for the two groups across the equations. The corresponding system of equations to solve can be written as follows:

$$
\begin{aligned}
& \mathrm{V}_{1, \mathrm{t}}=\alpha_{1, \mathrm{t}}+\beta_{1, \mathrm{t}}\left|\Delta \mathrm{P}_{1, \mathrm{t}}\right|+\xi_{1, \mathrm{t}} \\
& \dot{\cdot} \cdot \\
& \mathrm{V}_{\mathrm{n}, \mathrm{t}}=\alpha_{\mathrm{n}, \mathrm{t}}+\beta_{\mathrm{n}, \mathrm{t}}\left|\Delta \mathrm{P}_{\mathrm{n}, \mathrm{t}}\right|+\xi_{\mathrm{n}, \mathrm{t}}
\end{aligned}
$$

with the following dual linear equality constraint on the beta $\beta$ coefficients for the two groups

$$
\begin{aligned}
& \beta_{1}=\beta_{2}=\ldots \ldots \ldots=\beta_{20}=\beta_{i} \\
& \beta_{21}=\beta_{22}=\ldots \ldots . .=\beta_{33}=\beta_{j}
\end{aligned}
$$

where $\mathrm{V}_{\mathrm{nt}}$, is the trading volume of the nth security at time $\mathrm{t}, \Delta \mathrm{P}_{\mathrm{n}}$, is the change in price of the nth security at time $\mathrm{t}$, $\alpha_{\mathrm{n}}$, and $\beta_{\mathrm{n}}$, are (respectively) the ordinate at the origin and the sensitivity of trading volume to change in price of the nth security and $\xi_{\mathrm{n}}$, is the error term. $\beta_{\mathrm{i}}$ is the beta coefficient of option eligible equity issues $\mathrm{i}$ and, $\beta_{\mathrm{j}}$ is the beta coefficient of equity issues without options $\mathrm{j}$.

This empirical method has been used in many event studies in recent years. It circumvents the problem of possible correlation of the residual $\xi_{\mathrm{i}}$ across regression equations, since a change in price or in volume of one security included in the sample could conceivably trigger a change in other securities, and vice versa. Another advantage of the SUR method is that it incorporates all the information contained in the covariance matrix, thus enabling better parameter estimates. Forcing the linear equality constraint $\left(2-\mathrm{c}_{1}\right)$ upon the beta coefficients of all securities included in each group in the system of equations induces a portfolio effect. As a result, the estimate of beta coefficient measures the average effect of a price change on trading volume of all securities included in each group rather than a firm specific effect.

To test the impact of the options market on the price-volume relationship, we compare the $\beta_{\mathrm{i}}$ coefficients of option eligible equity issues with the $\beta_{\mathrm{j}}$ coefficients of option ineligible equity issues. In the comparison test, the $\beta_{\mathrm{i}}$ and $\beta_{\mathrm{j}}$ coefficients are estimated simultaneously from the same system of equations (2) subject to constraint $\left(2-\mathrm{c}_{2}\right)$ 
using the same SUR procedure. This has the advantage of greater efficiency over the traditional method, where each of the betas would be estimated separately, followed by a comparison using the group means. The equality constraints on the averages of the beta coefficients of the two groups of securities can be written as follows:

$\left(2-c_{2}\right) \quad \mathrm{m}_{\mathrm{op}}=1 / 20 \underset{\mathrm{i}=1}{\sum \beta_{\mathrm{i}}}=\mathrm{m}_{\mathrm{nop}}=1 / 13 \underset{\mathrm{j}=1}{\sum} \beta_{\mathrm{j}}$

where $\beta_{\mathrm{i}}$ is the beta coefficient of option eligible equity issue $\mathrm{i}, \beta_{\mathrm{j}}$ is the beta coefficient of option ineligible equity issue $\mathrm{j}, \mathrm{m}_{\mathrm{op}}$ is the mean of betas of option eligible securities and, $\mathrm{m}_{\text {nop }}$ is the mean of betas of option ineligible securities.

If the options market has an effect on the absolute price-volume relationship $(\mathrm{V}-\Delta \mathrm{P})$, then the coefficient of the $\beta_{i}$ parameter of option eligible securities should be significantly different from that of option ineligible securities. To conduct the analysis, we will begin by verifying the presence of linearity between volume and absolute price change for the individual securities and the two groups of securities. Building on that result, we will test the difference of volume sensitivity between the two groups.

\section{EMPIRICAL RESULTS}

\section{A) Evidence of the Positive Volume-Absolute Price Change Relationship}

To verify the presence of the positive relationship between volume and absolute price change relationship, we estimate equation (1) using data on the 33 individual securities of the two groups. In order to keep continuity in the data, we have retained 33 stocks instead of 35 in the sample because two stocks were dropped from the index and replaced by 2 others during the period covered by the study. To circumvent the problems of first order serial correlation in the residuals, we use the Yule-Walker iterative procedure available on SAS ETS.

Under the null hypothesis, the estimate of coefficient $\beta$ should not be statistically different from zero. A value of $\beta$ greater than zero would indicate the presence of positive correlation between volume and absolute price change.

Table 1 presents the estimates for the parameters of equation (1) where the price change is measured by the close to close price change $\left(\Delta \mathrm{P}_{\mathrm{cc}}\right)$.

Table 1

Relationship Between Trading Volume And Absolute Price Change

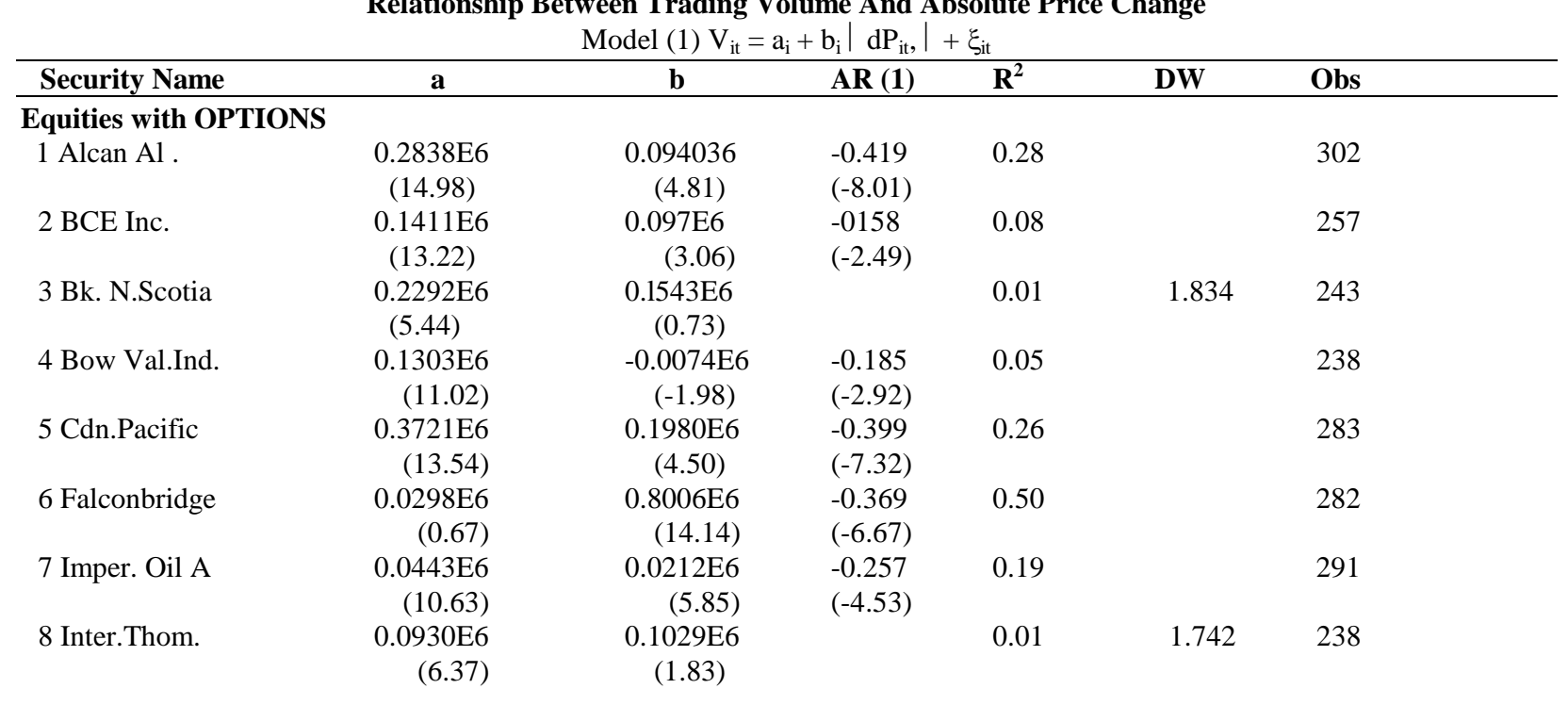


Table 1 continued

Relationship Between Trading Volume And Absolute Price Change

\begin{tabular}{|c|c|c|c|c|c|c|}
\hline Security Name & $\mathbf{a}$ & b & AR (1) & $\mathbf{R}^{2}$ & DW & Obs \\
\hline \multicolumn{7}{|c|}{ Equities with OPTIONS } \\
\hline 9 Moore Corp. & $\begin{array}{r}0.0873 \mathrm{E} 6 \\
(9.17)\end{array}$ & $\begin{array}{c}0.0652 \mathrm{E} 6 \\
(4.42)\end{array}$ & $\begin{array}{l}-0.209 \\
(-3.63)\end{array}$ & 0.09 & & 287 \\
\hline 10 Inco Limited & $\begin{array}{r}0.2479 \mathrm{E} 6 \\
(12.28)\end{array}$ & $\begin{array}{c}0.0934 \mathrm{E} 6 \\
(4.62)\end{array}$ & $\begin{array}{l}-0.337 \\
(-6.18)\end{array}$ & 0.21 & & 296 \\
\hline 11 North.Tele. & $\begin{array}{r}0.1183 \mathrm{E} 6 \\
(9.55)\end{array}$ & $\begin{array}{c}0.0987 \mathrm{E} 6 \\
(5.25)\end{array}$ & $\begin{array}{l}-0.310 \\
(-5.49)\end{array}$ & 0.20 & & 282 \\
\hline 12 N.Corp. Alb. & $\begin{array}{r}0.0109 \mathrm{E} 6 \\
(0.13)\end{array}$ & $\begin{array}{c}0.6764 \mathrm{E} 6 \\
(9.69)\end{array}$ & $\begin{array}{l}-0.343 \\
(-5.82)\end{array}$ & 0.38 & & 252 \\
\hline 13 Placer Dome & $\begin{array}{r}0.2293 \mathrm{E} 6 \\
(10.21)\end{array}$ & $\begin{array}{c}0.2513 \mathrm{E} 6 \\
(5.51)\end{array}$ & $\begin{array}{l}-0.181 \\
(-3.02)\end{array}$ & 0.18 & & 268 \\
\hline 14 Power Corp. & $\begin{array}{r}0.0692 \mathrm{E} 6 \\
(8.78)\end{array}$ & $\begin{array}{c}0.0035 \mathrm{E} 6 \\
(0.14)\end{array}$ & $\begin{array}{l}-0.361 \\
(-6.09)\end{array}$ & 0.14 & & 247 \\
\hline 15 Ranger Oil & $\begin{array}{r}0.0889 \mathrm{E} 6 \\
(1.89)\end{array}$ & $\begin{array}{c}0.4505 \mathrm{E} 6 \\
(2.36)\end{array}$ & $\begin{array}{l}-0.271 \\
(-4.31)\end{array}$ & 0.11 & & 232 \\
\hline 16 Royal Bank & $\begin{array}{r}0.1368 \mathrm{E} 6 \\
(9.02)\end{array}$ & $\begin{array}{c}0.1411 \mathrm{E} 6 \\
(3.50)\end{array}$ & $\begin{array}{l}-0.181 \\
(-3.00)\end{array}$ & 0.08 & & 264 \\
\hline 17 Sears Canada & $\begin{array}{r}0.0118 \mathrm{E} 6 \\
(0.47)\end{array}$ & $\begin{array}{c}0.3017 \mathrm{E} 6 \\
(2.72)\end{array}$ & & 0.04 & 1.940 & 226 \\
\hline 18 Stelco Ser.A & $\begin{array}{r}0.0547 \mathrm{E} 6 \\
(7.82)\end{array}$ & $\begin{array}{c}0.0415 \mathrm{E} 6 \\
(3.06)\end{array}$ & $\begin{array}{l}-0.307 \\
(-5.22)\end{array}$ & 0.12 & & 260 \\
\hline 19 Tor.Dom.Bk. & $\begin{array}{r}0.1101 \mathrm{E} 6 \\
(10.30)\end{array}$ & $\begin{array}{c}0.1262 \mathrm{E} 6 \\
(4.76)\end{array}$ & & 0.08 & 1.815 & 270 \\
\hline 20 Seagrams & $\begin{array}{r}0.0591 \mathrm{E} 6 \\
(16.34)\end{array}$ & $\begin{array}{c}0.0126 \mathrm{E} 6 \\
\quad(5.02)\end{array}$ & $\begin{array}{l}-0.222 \\
(-3.93)\end{array}$ & 0.15 & & 297 \\
\hline \multicolumn{7}{|c|}{ Equities without OPTION } \\
\hline 21 Bk.of Mtreal & $\begin{array}{c}0.0839 \mathrm{E} 6 \\
(5.10)\end{array}$ & $\begin{array}{c}0.2225 \mathrm{E} 6 \\
(2.91)\end{array}$ & & 0.06 & 2.056 & 246 \\
\hline 22 C.A.E.Indust & $\begin{array}{r}0.0930 \mathrm{E} 6 \\
(5.97)\end{array}$ & $\begin{array}{c}0.1107 \mathrm{E} 6 \\
(0.88)\end{array}$ & $\begin{array}{l}-0.184 \\
(-2.92)\end{array}$ & 0.06 & & 243 \\
\hline 23 Cdn. Imper.Bk Y & $\begin{array}{r}0.1490 \mathrm{E} 6 \\
(8.25)\end{array}$ & $\begin{array}{c}0.1708 \mathrm{E} 6 \\
(3.99)\end{array}$ & $\begin{array}{l}-0.431 \\
(-7.94)\end{array}$ & 0.24 & & 276 \\
\hline 24 Cdn.Tire C.A & $\begin{array}{r}0.0650 \mathrm{E} 6 \\
(8.77)\end{array}$ & $\begin{array}{c}0.0932 \mathrm{E} 6 \\
(3.61)\end{array}$ & & 0.06 & 1.851 & 248 \\
\hline 25 Echo Bay M. & $\begin{array}{r}0.0955 \mathrm{E} 6 \\
(13.67)\end{array}$ & $\begin{array}{c}0.0366 \mathrm{E} 6 \\
(5.54)\end{array}$ & $\begin{array}{c}-0.274 \\
(-4.93)\end{array}$ & 0.18 & & 294 \\
\hline 26 Imasco Ltd. & $\begin{array}{r}0.0519 \mathrm{E} 6 \\
(7.25)\end{array}$ & $\begin{array}{c}0.0645 \mathrm{E} 6 \\
(4.31)\end{array}$ & & 0.10 & 1.777 & 278 \\
\hline 27 Laidlaw, C.B & $\begin{array}{r}0.2271 \mathrm{E} 6 \\
(5.69)\end{array}$ & $\begin{array}{r}0.605 \mathrm{E} 6 \\
(9.62)\end{array}$ & $\begin{array}{l}-0.402 \\
(-7.12)\end{array}$ & 0.42 & & 261 \\
\hline 28 MacMil.Bld. & $\begin{array}{r}0.0862 \mathrm{E} 6 \\
(10.03)\end{array}$ & $\begin{array}{c}0.1190 \mathrm{E} 6 \\
(7.62)\end{array}$ & $\begin{array}{l}-0.162 \\
(-2.68)\end{array}$ & 0.25 & & 266 \\
\hline 29 National Bk. & $\begin{array}{r}0.1125 \mathrm{E} 6 \\
(5.75)\end{array}$ & $\begin{array}{c}0.0349 \mathrm{E} 6 \\
(0.46)\end{array}$ & $\begin{array}{l}-0.211 \\
(-3.34)\end{array}$ & 0.05 & & 239 \\
\hline 30 Noranda Inc. & $\begin{array}{r}0.1522 \mathrm{E} 6 \\
(8.67)\end{array}$ & $\begin{array}{c}0.2330 \mathrm{E} 6 \\
(7.35)\end{array}$ & $\begin{array}{l}-0.181 \\
(-3.08)\end{array}$ & 0.22 & & 279 \\
\hline 31 Southam Inc. & $\begin{array}{r}0.0337 \mathrm{E} 6 \\
(5.23)\end{array}$ & $\begin{array}{c}0.0267 \mathrm{E} 6 \\
(1.85)\end{array}$ & $\begin{array}{l}-0.192 \\
(-3.21)\end{array}$ & 0.05 & & 267 \\
\hline 32 TransAlta U. & $\begin{array}{r}0.0845 \mathrm{E} 6 \\
(9.61)\end{array}$ & $\begin{array}{c}-0.0350 \mathrm{E} 6 \\
(-1.09)\end{array}$ & & 0.00 & 1.816 & 231 \\
\hline 33 TranSCdn.Pip. & $\begin{array}{r}0.0363 \mathrm{E} 6 \\
(3.80)\end{array}$ & $\begin{array}{c}0.2806 \mathrm{E} 6 \\
(9.04)\end{array}$ & $\begin{array}{l}-0.147 \\
(-2.30)\end{array}$ & 0.27 & & 239 \\
\hline
\end{tabular}

Parentheses contain the t-statistics 
As Table 1 shows, the estimate for parameter $\beta$ is positive and significant for 29 out of the 33 securities indicating the presence of a positive correlation between volume and absolute price change measured by $\Delta \mathrm{P}_{\mathrm{cc}}$. One security exhibits negative correlation, and among the three others which exhibit a non significant relationship, two have a positive $\beta$. In overall terms, we can say that the data display a positive volume absolute price change correlation supporting the findings of prior studies.

The analysis of the correlation for the option eligible and option ineligible security groups is conducted by estimating the equation (2) subject to the dual linear equality constraint (2-c $)$ using data on each of the two groups of securities. Table 2 shows the result of the estimation.

Table 2

Estimates of the $\beta_{i}$ and $\beta_{j}$ Coefficients With Dual Equality Constraint

\begin{tabular}{|c|c|c|c|}
\hline$|\Delta \mathrm{P}|$ & $\Delta \mathrm{P}_{\mathrm{cc}}$ & $\Delta \mathrm{P}_{\mathrm{oc}}$ & $\Delta \mathrm{P}_{\mathrm{hl}}$ \\
\hline Option Eligible & $0.0139 \mathrm{E} 6$ & $0.0205 \mathrm{E} 6$ & $0.0007 \mathrm{E} 6$ \\
Equities coeff. $\beta_{\mathrm{i}}$ & $(8.96)$ & $(10.56)$ & $(1.99)$ \\
& & & $0.0405 \mathrm{E} 6$ \\
Option Ineligible & $0.0497 \mathrm{E} 6$ & $0.0478 \mathrm{E} 6$ & $(12.37)$ \\
Equities coeff. $\beta_{\mathrm{j}}$ & $(12.31)$ & $(10.14)$ & \\
securities & & & \\
\hline
\end{tabular}

The t statistics are shown in parentheses.

As Table 2 indicates, the estimates of the $\beta_{\mathrm{i}}$ and $\beta_{\mathrm{j}}$ coefficients are positive and significantly different from zero for the different measures of price change used. These results indicate that, irrespective of how change in price is measured, volume of transactions is positively correlated to the absolute value of the price change for both groups of securities. This confirms the results of previous studies which have shown that a large variation in price brings about, on average, a large volume of transactions. This finding shows that the introduction of the options market does not modify the nature of the documented positive relationship between volume and absolute price change. Whether a security is option eligible or not, an important change in its price brings about a large trading volume. This confirms the Wall Street adage "It takes volume to make price move" securities.

The rest of the paper will compare the sensitivity of volume to the price change for the two groups of

\section{B) Comparison Test of the Sensitivity of $\mathrm{V}$ to $|\Delta \mathrm{P}|$ for Option Eligible Securities Versus Option Ineligible Securities.}

To proceed with the comparison test, we estimate the system of equations (2) with constraint $\left(2-\mathrm{c}_{2}\right)$. According to our hypothesis, because of the advantages attached to the options market, the trading volume of an option eligible security should be less sensitive to price change than that of a security without options. It follows that the option eligible securities' mean betas, $\left(\mathrm{m}_{\mathrm{op}}\right)$ differs statistically from the option ineligible securities' mean betas, $\left(\mathrm{m}_{\text {nop }}\right)$. The estimated values of beta coefficients are shown in Table 3.

As Table 3 shows, the estimated values of beta coefficients are all significantly positive and the estimate of the $\beta_{\mathrm{i}}$ coefficient of the option eligible securities is statistically different from that of the $\beta_{\mathrm{j}}$ coefficient of the option ineligible securities. Indeed, the values for the F-statistic indicate that for the measures of price change used, the equality hypothesis of betas, $\left(\mathrm{H}_{0}\right)$, is rejected at a confidence level of 0.01 , meaning that the volume of transactions in option eligible securities is less sensitive to a change in its price than is the volume of transactions in option ineligible securities. 
Table 3

Comparison Test of Beta Coefficients

With Equality Constraints on the Means

\begin{tabular}{|c|c|c|c|c|}
\hline \multirow[b]{2}{*}{ Price Changes } & \multicolumn{2}{|c|}{ Mean Beta Coefficients } & \multirow[b]{2}{*}{$\mathbf{F}$} & \multirow[b]{2}{*}{$\mathbf{P}$} \\
\hline & Option Eligible & Option Ineligible & & \\
\hline$\Delta \mathrm{P}_{\mathrm{cc}}$ & $\begin{array}{c}0.2785 \mathrm{E} 6 \\
(8.96)\end{array}$ & $\begin{array}{c}0.6465 \mathrm{E} 6 \\
(12.31)\end{array}$ & 9.19 & 0.0024 \\
\hline$\Delta \mathrm{P}_{\mathrm{oc}}$ & $\begin{array}{c}0.2599 \mathrm{E} 6 \\
(10.56)\end{array}$ & $\begin{array}{c}0.6215 \mathrm{E} 6 \\
(10.14)\end{array}$ & 8.02 & 0.043 \\
\hline$\Delta \mathrm{P}_{\mathrm{hl}}$ & $\begin{array}{c}0.0152 \mathrm{E} 6 \\
(1.99)\end{array}$ & $\begin{array}{c}0.5259 \mathrm{E} 6 \\
(12.37)\end{array}$ & 120.54 & 0.0001 \\
\hline
\end{tabular}

The t statistics are shown in parentheses.

When new information hits the market, since investors have an opportunity to react to that information both in the stock market and in the options market, the trading volume of option eligible securities is less correlated with price change than is the case for option ineligible securities. Indeed, the presence of the options market makes it possible, for instance, for an investor to cover a position in the stock market without having to actually trade in that market. As the information arrives in the stock market, he can use options to implement his trading strategy. Therefore, the trading volume of option eligible securities resulting from a price change is likely to be less than in the case of option ineligible securities. According to Beaver (1968), inferences can be made from a combination of volume and price in event studies. The implication of the present study is that one also has to take into account what occurs in the options market, at least in the case of option eligible securities. For instance, the investor who uses the Dow theory as an investment strategy has to integrate both stock market movements and options market movements in order to be successful in forecasting how a security will behave.

Finally, the results support our contention that investors are less likely to directly compromise their holdings in securities with options, since the options market makes it possible for them to more efficiently pursue their various investment strategies at lower cost. However, it is important to point out that the willingness of investors to trade on the options market does not modify the nature of the observed relationship between volume and price change.

\section{CONCLUSION}

Our objective in this paper was to compare the relationship between volume of transactions and price changes for option eligible and option ineligible securities, to determine the extent to which the price-volume relationship is affected by the options market. On the one hand, the finding indicates that even though there are some advantages attached to options trading, there is still a positive linear relationship between volume-absolute price change in option eligible securities, meaning that the introduction of the options market has not radically changed the nature of the observed price-volume relationship. On the other hand, the findings of our analysis confirm the notion that investors may be more inclined to turn to the options market rather than acting directly on the securities in order to carry out their different investment and coverage strategies on the stock market. Indeed, the results do show that the trading volume in option eligible securities is on average less sensitive to price changes than is the volume of option ineligible securities. Consequently, when dealing with an option eligible security, investment strategies which use both volume and price change to make inferences must include both stock and option markets in their analysis. It will be interesting to see if these results hold true with other set of data and also in different countries. 


\section{REFERENCES}

1. Beaver, William H. "Alternative Accounting Measures as Predictors of Failure". The Accounting Review, 43, no. 1 (January 1968)

2. Black, F. and M. Scholes. "The Pricing of Options and Corporate Liabilities", Journal of Political Economy, 81 (May-June 1973), 637-654.

3. Boluch, Michael J and Trevor W Chamberlain "Option volume and stock price behavior: Some evidence from the Chicago Board Options Exchange" Edwardsville: Dec 1997. Vol. 25, Iss. 4; pg. 358, 13 pgs

4. Chamberlain, Cheung and Kwan, "Volume-Price Change Relations and The Costly Short Sales Hypothesis: Some Empirical Tests" Journal of Administrative Sciences, vol. 8, No. 3 (September 1991), 175-178.

5. Copeland, T. E., "A Model of Asset Trading under the Assumption of sequential Information Arrival", Journal of Finance, 31 (September 1976), 1149-1168.

6. $\quad$ "A Probability Model of Asset Trading", Journal of Financial and Quantitative Analysis, 12 (Novembre 1977), 563578.

7. $\quad$ Epps, T. W., "Security Price Changes and Transaction Volumes: Theory and Evidence", American Economic Review, 65 (September 1975), 586-597.

8. Glickstein, D. A. and R. E. Wubbels, "Dow Theory is alive and Well", Journal of Portfolio Management, 9 No. 3 (Spring 1983) 28-32.

9. Harris, L. "Cross-Security Tests of the Mixture of Distributions Hypothesis", Journal of Financial and Quantitative Analysis, 21 (March 1986), 39-46.

10. Jennings, R. H., L. T. Starks and J. C. Fellingham, "An Equilibrium Model of Asset Trading with Sequential Information Arrival", Journal of Finance, 36 (March 1981), 143-161.

11. Karpoff, J. M., "The Relation between Price Changes and Trading Volume: A Survey", Journal of Financial and Quantitative Analysis, 22 (March 1987).

12. "Costly Short Sales and the Correlation of Returns With Volume", The Journal of Financial Research, Vol. 51, No.2 Fall 1988, pp.173-188.

13. Osborne, M. F. M. "Brownian Motion in the Stock Market". Operations Research, 7 March-April 1959, 145-173.

14. Pfleiderer, P., "The Volume of Trade and the Variability of Prices: A Framework for Analysis in Noisy Rational Expectations Equilibria", Working Paper, Stanford University (May 1984).

15. Rogalski, R. J., "The Dependance of Prices and Volume", The Review of Economics and Statistics, 36 (May 1978), 268-274.

16. Ross, Stephan, "Options and Efficiency" Quarterly Journal of Economics, February 1976.

17. Sarwar, Ghulam, "The Informational Role of Option Trading Volume in Equity Index Options Markets" Review of Quantitative Finance and Accounting. Boston: Mar 2005. Vol. 24, Iss. 2; pg. 159

18. Santoni, G. J. (1988). "The October Crash: Some Evidence on the Cascade Theory", The Journal of Futures Markets, May-June (1988), pp 18-33.

19. Schneller, M. E. "Security Price Changes and Transaction Volumes: Comment". Americain Economic Review, 68 (Sept.1978).

20. Tauchen, G. and M. Pitts., "The Price Variability-Volume Relationship on Speculative markets", Econometrica, 51 (March 1983), 485-505. 